\title{
Lapse kuvandist täiskasvanute ja laste endi pilgu läbi
}

\author{
Andra Reinomägi \\ Tartu Ülikooli ühiskonnateaduste instituudi sotsioloogia doktorant \\ andra.reinomagi@ut.ee
}

\begin{abstract}
Teesid: Artikkel lahkab lapse kuvandit laste ja täiskasvanute vaatenurgast lähtuvalt ning selgitab välja, kuivõrd on arusaamad lapse kuvandist laste ja täiskasvanute hulgas erinevad. Selleks võrreldakse laste ja täiskasvanute seas levinud arusaamu lastest. Samuti vaadatakse, millise sotsiaaldemograafilise taustaga täiskasvanud neid arusaamu esindavad. Analüüs põhineb "Lapse õiguste ja vanemluse uuringu" (2018) andmetel, mis annab unikaalse võimaluse võrrelda sama metoodika alusel laste ja täiskasvanute seisukohti. Analüüsi tulemustest selgub, et lastega võrreldes näevad täiskasvanud lapsi sagedasti kaitset vajavate, ornade ja haavatavate isikutena, kes teadmatutena vajavad nõu ja juhendamist. Sealjuures toetavad täiskasvanud tugevalt ka kompetentse lapse kuvandit, mille järgi lastel on oma arvamused ja eelistused, millega on oluline arvestada. Lapsed ise näevad end kõige sagedamini just kompetentsetena, samas peegeldub laste hinnangutes ka laste kaitsmise ja täiskasvanute-poolse kontrolli vajadus. Ilmneb, et naiste ja meeste ning erinevast rahvusest inimeste hulgas on levinud erinev kuvand lastest. Täiskasvanute puhul tuleb välja, et lapse kuvand ja arusaam lapsest sõltub vastaja haridusest. Oluliselt määrab lapse kuvandit täiskasvanu enda vahetu kogemus ehk alaealiste laste olemasolu leibkonnas, samuti see, kas inimene on kuulnud lapse õigustest või mitte. Uuringu tulemused peegeldavad laste positsiooni ühiskonnas, aitavad mõista laste ja täiskasvanute vahelisi suhteid ning on aluseks edasistele laste olukorda ja võimalusi kirjeldavatele uurimustele.
\end{abstract}

Märksõnad: lapse kuvand, lastega seotud hoiakud, laste positsioon ühiskonnas, lapse õigused

\section{Sissejuhatus}

Lapsed moodustavad ühiskonnast olulise osa ning lapsepõlv moodustab iga inimese elust samuti märkimisväärse perioodi. Ajaloo jooksul on lapsi kui ühiskonnaliikmeid nähtud väga erinevalt. Sotsioloogias, mis uurib inimeste ja ühiskonna seoseid, on pikka aega käsitletud lapsi kui kedagi, kes pole veel päriselt täiskasvanu ja kes peavad alles küpsema ja valmistuma inimeseks (täiskasvanuks) saama (Ben-Arieh 2008; James \& Prout 2015). Kritiseerides lapsepõlve uurimise praktikaid, toob Asher Ben-Arieh (2008) varasemate uuringute puudusena välja tulevikku suunatud vaatenurga (laps kui alles 
täiskasvanuks saav - inglise keeles becoming), selmet kirjeldada lapsepõlve siin ja praegu (laps kui tänases päevas olija - inglise keeles being).

Taani sotsioloog Jens Qvortrup (1987) oli üks esimestest, kes rõhutas sotsioloogias laste ja lapsepõlve kui eraldiseisva institutsiooni või ühiskondliku struktuuriosa uurimist. Uue aja lapsepõlve uurivast sotsioloogiast rääkides käsitleb Doris Bühler-Niederberger (2010) teiste teadusvaldkondade mõjusid sellele, tuues välja näiteks psühholoogia, pedagoogika ja neuroteaduste teadmised, mida tänapäeva lapsepõlvesotsioloogias arvestatakse ja mis on mõjutanud ühiskonna teadlikkust lastest ja lapsepõlvest. Ka Qvortrup (1991) nimetab erinevate teadusharude n-ö laste suundade (psühholoogia, lastepsühhiaatria, pediaatria) arengut, mille käigus hakati lastele kui eraldiseisvale ühiskonnagrupile enam tähelepanu pöörama. Iseseisvate ja kompetentsetena, siin ja praegu tegutsejatena on lapsi hakatud nägema alles viimastel aastakümnetel. Lapse õiguste põhimõtete areng ja ÜRO lapse õiguste konventsioon on tugevat mõju avaldanud ka laste ja lapsepõlve uurimisele (vt nt Qvortrup 1987; Corsaro 2011). Lapse õigustest kui laste heaolu alusraamistikust lähtuvalt saab kirjeldada laste võimalusi, arengut ja positsiooni võrreldes teiste ühiskonnaliikmetega (Kutsar 2008). Mitmed uurijad (nt Andrews et al. 2002; Jonsson \& Östberg 2010) toovad välja, et laste inim- ja kodanikuõigused, sotsiaalne õiglus ja kodanikuühiskonnas osalemine on seotud nende heaoluga. Ühiskonnas osalemine eeldab võimalust olla nähtud, kuuldud ja aktsepteeritud ning osaleda aktiivselt ühiskonnaelu küsimustes. Tingimused selleks kujunevad välja laste ja neid ümbritseva keskkonna koosmõjudes, mille kohta on erialases kirjanduses mitmeid mudeleid (nt Urie Bronfenbrenneri (1979) ökoloogiline süsteemiteooria, William Corsaro (2011) last ümbritseva võrgustiku mudel, Jaana Minkkineni (2013) lapse heaolu struktuurne mudel). Kõigi nende mudelite ühine põhimõte sedastab, et ühiskonnas valitsevad väärtused ja hoiakud mõjutavad last ja lapse võimalusi ühiskonnas.

Sotsiaalkonstruktsionistliku käsitluse järgi on lapsepõlv sotsiaalselt konstrueeritud nähtus, mis mõjutab laste võimalusi olla kuuldud ja ühiskonnas osaleda (Qvortrup 2014). Leena Alanen (2014) toob laste ja lapsepõlve konstrueerimisest kirjutades välja, et kollektiivsed kuvandid lapsest, lastest ja lapsepõlvest on kultuurilised konstruktsioonid, mis mõjutavad laste igapäevast reaalsust ja kujundavad lastega seotud uskumusi, mõjutades käitumist, kultuurilisi praktikaid ning muuhulgas ka erinevate poliitikate, sh heaolu poliitikate kujundamist. Inimeste arusaamad on Alaneni (2014) järgi seotud käitumisega ning mõjutavad seeläbi nii lapsi kui ka lapsepõlve.

Kultuuriliste, sotsiaalsete ja majanduslike tegurite ning ümbritseva keskkonna koosmõju arvestamise kõrval (Frønes 1993) on William Corsaro (2011) hinnangul ühiskondlike suhete kirjeldamisel oluline arvestada ka laste endi 
poolt loodavat kultuuri, laste suhteid ja mõjusid ühiskonnas. Allison Jamesi ja Alan Prouti (2015) käsitluses on lapsed aktiivsed ühiskonnaliikmed, kes mõjutavad oma elu ja ennast ümbritsevaid suhteid. Ross A. Thompson (2014) toob laste ja täiskasvanute suhete seotusest rääkides välja, et ühiskonnas levinud kultuurinormid ja väärtused kanduvad lasteni suhete kaudu. Kultuur, mis kõige laiemalt võttes sisaldab ühiskonna väärtusi ja norme, mõjutab inimeste käitumist ja hoiakuid laste suhtes (Minkkinen 2013). Need on vastastikuses seoses laste endi käitumisega, avaldades üksteisele mõju ja peegeldudes üksteises. Täiskasvanud kui eeskujud mõjutavad suhete kaudu lapse enesehinnangut ja lapse kuvandit iseendast kui lapsest (Thompson 2014). Viis, millisena lapsed end ise näevad, mõjutab Thompsoni (2014) järgi nende käitumist ja suhestumist täiskasvanutega ning vastastikusest suhtlemisest saadud kogemused loovad uuesti lapse mina-pilti.

Seega võib öelda, et nii täiskasvanutel kui ka lastel endil on märkimisväärne roll laste kuvandi kujundamisel. Seetõttu on sotsioloogilisest vaatenurgast lähtuvalt oluline uurida, kuidas lapsed end ise näevad, sest nende minapilt määratleb laste rolli ja positsiooni täiskasvanute suhtes (Ben-Arieh \& KhouryKassabri 2008). Samaväärselt oluline on uurida täiskasvanute hulgas valitsevaid lapse kuvandeid, kuna see määratleb nende käitumise ja suhtumise lapsesse (Alanen 2014).

Prantsuse ajaloolane Phillipe Ariès oli üks esimesi, kes kirjutas lastest ja lapsepõlvest ajaloolises võtmes. Alustades ajalooliselt kaugemast perioodist, märgib Ariès (Ariès 1979, viidanud Morrow 2011), et keskajal, mil eraldi lapsepõlve mõistet polnud, olid lapsed täiskasvanute kõrval samasugused ühiskonnaliikmed, kes tegid tööd ja osalesid neid ümbritsevas kogukonnaelus. Harry Hendrick, kes on samuti kirjeldanud erinevaid ajaloolisi lapse ja lapsepõlve käsitlusi, toob näiteid erinevatel aegadel valitsenud hoiakutest laste ja lapsepõlve suhtes. Nii näiteks saab välja tuua nn loomuliku lapse vaate, mille puhul nähakse last kui puhast lehte - tabula rasat - ja väärtustatakse lapseks olemist enne täiskasvanuks saamist (Hendrick 2015). Romantilises lapsepõlve käsitluses nähakse Hendricku (2015) järgi last ja lapsepõlve süütuse ja puhtuse võrdkujuna, mida tuleks alles hoida tulevikus, täiskasvanuks saades, et see toidaks kogu järgnevat elu. Süütu lapse kuvandit iseloomustab Hendricku (2015) järgi kaitse, juhendamise, aga ka armastuse ja distsipliini vajadus. Sama toob välja ka Barry Goldson (1997), kes laste ja lapsepõlve erinevatest käsitlustest rääkides viitab laste haavatavusele ja nende kaitsmise vajadusele. Laste kaitsmine ja lapse parimate huvide eest seismine on selle lähenemise puhul täiskasvanute ülesanne, mis annab seeläbi raami ka laste ja täiskasvanute omavahelisele suhtele. 
Helgematele lapse käsitlustele vastanduvad aga rangemad ja karmimad hinnangud lastele ja lapsepõlvele. Näiteks toob Hendrick (2015) välja ka iseka, sõltumatu, pahatahtliku, allutamatu ja normist hälbiva lapse, kes vajab korralekutsumist ja jõule allutamist. Eelnevaga seondub ka naiivse ja egoistliku lapse kuvand, mille puhul on lapse peamine eesmärk asjade omamine, võim ja tähelepanu (Hendrick 2015). Ühiskonnauurija ja kriminoloog Phil Scraton (1997) on egoistliku ja distsipliini vajava lapse puhul toonud välja kõrvale kaldumise n-ö peavoolu normist, olgu siis haridussüsteemis, kirikus või kodus, mille järgi lastel puudub vastutustundlikkus ning seetõttu vajavad nad täiskasvanute suunamist. Scratoni (1997) hinnangul on laste ja täiskasvanute suhtlemisel küsimus võimusuhetes, mille puhul täiskasvanud kontrollivad lapsi.

Allison James ja Alan Prout viitavad Donald G. MacKayle, kes tugineb ajaloolistest lähenemistest lastele ja lapsepõlvele kirjutades sotsialiseerimisteooriale ja toob sellest lähtuvalt välja laste kui ebaküpsete, irratsionaalsete, ebakompetentsete, mittesotsiaalsete ja kultuuritute isikute kuvandi, erinevalt täiskasvanutest, kes on küpsed, ratsionaalsed, kompetentsed, sotsiaalsed ja iseseisvad (MacKay 1973, viidanud James \& Prout 2015). Seega võib öelda, et erinevalt keskajast, mil lapsepõlve ei käsitletud ühiskonnas eraldi, on hilisematel perioodidel romantilise ja süütu lapse kuvandite kõrval vaadeldud lapsi ka kui juhendamist, õpetamist, aga ka kontrolli ja karmi distsipliini vajavaid isikuid.

Eelöeldust nähtub, et viise, millisena on lapsi läbi ajaloo nähtud ja kuidas sotsioloogilistes uurimustes käsitletud, on väga erinevaid. Eestis on laste kuvandeid käsitletud lapse õiguste ja vanemluse monitooringus, mis viidi esmakordselt läbi 2012. aastal (Karu et al. 2012) ja teine laine 2018. aastal lapse õiguste ja vanemluse uuringuna (Anniste et al. 2018). Selles puudutati lapse õiguste ja vanemlusega seotud küsimuste kõrval ka seda, millisena lapsi üldiselt nähakse. Toetudes Barry Goldsoni (1997) ja Phil Scratoni (1997) käsitlustele toovad mõlema uurimuse autorid esile neli kuvandi tüüpi: ebaküpse, haavatava, vastutustundetu ja kompetentse lapse kuvand (joonis 1). Nimetatud mudel on üks võimalik viis võtta kokku erinevad vaated lastele.

Käesoleva artikli eesmärk on iseloomustada lapse kuvandit Eestis laste ja täiskasvanute vaatenurgast lähtuvalt. Analüüsi esimeseks uurimisküsimuseks on see, mil määral toetasid lapsed ja täiskasvanud uuringus esitatud erinevaid laste olemust kirjeldavaid väiteid. Teiseks küsimuseks on see, kuidas uuringus esitatud väited suuremateks kuvandit peegeldavateks kogumiteks (faktoriteks) koonduvad ja selgitada, kuivõrd laste ja täiskasvanute kuvandid lastest omavahel kattuvad või eristuvad. Kolmanda küsimusena võrreldakse saadud tulemust algse teoreetilise mudeliga (joonis 1) ja otsitakse, milline mudel sobib lapse kuvandeid laste ja täiskasvanute hulgas paremini kirjeldama. Viimase 
uurimisküsimusena proovitakse selgitada, kuivõrd varieeruvad lastega seotud kuvandid vastavalt vastaja sotsiaaldemograafilisele profiilile.

\section{Andmed, valim ja analüüsimeetod}

Analüüsi aluseks on "Lapse õiguste ja vanemluse uuringu" andmed (Anniste et al. 2018). Selle uuringu unikaalsus Eesti jaoks tuleneb sellest, et sarnaselt 2012. aasta küsitlusega küsiti samu küsimusi nii laste kui ka täiskasvanute käest, mida teadaolevalt sel moel Eestis varem tehtud pole. Uuringu tellis Sotsiaalministeerium ja see valmis Euroopa Regionaalarengufondi "Valdkondliku teadus- ja arendustegevuse tugevdamise" programmi (RITA) tegevus 2 "Teadmistepõhise poliitikakujundamise toetamine" rahastamisel.

Ühe olulise teemana käsitleti uuringus seda, millisena lapsi üldiselt nähakse. Selleks paluti vastajatel hinnata, kuivõrd nad nõustuvad laste võimalikku olemust kirjeldava 16 väitega. Lapse kuvandi mõõtmise operatsionaliseerimise on nende väidete alusel teinud kaks autorite kollektiivi (Karu et al. 2012; Anniste et al. 2018), tuues välja nelja kuvandit hõlmava teoreetilise mudeli: ebaküpse, haavatava, vastutustundetu ja kompetentse lapse kuvand (joonis 1).

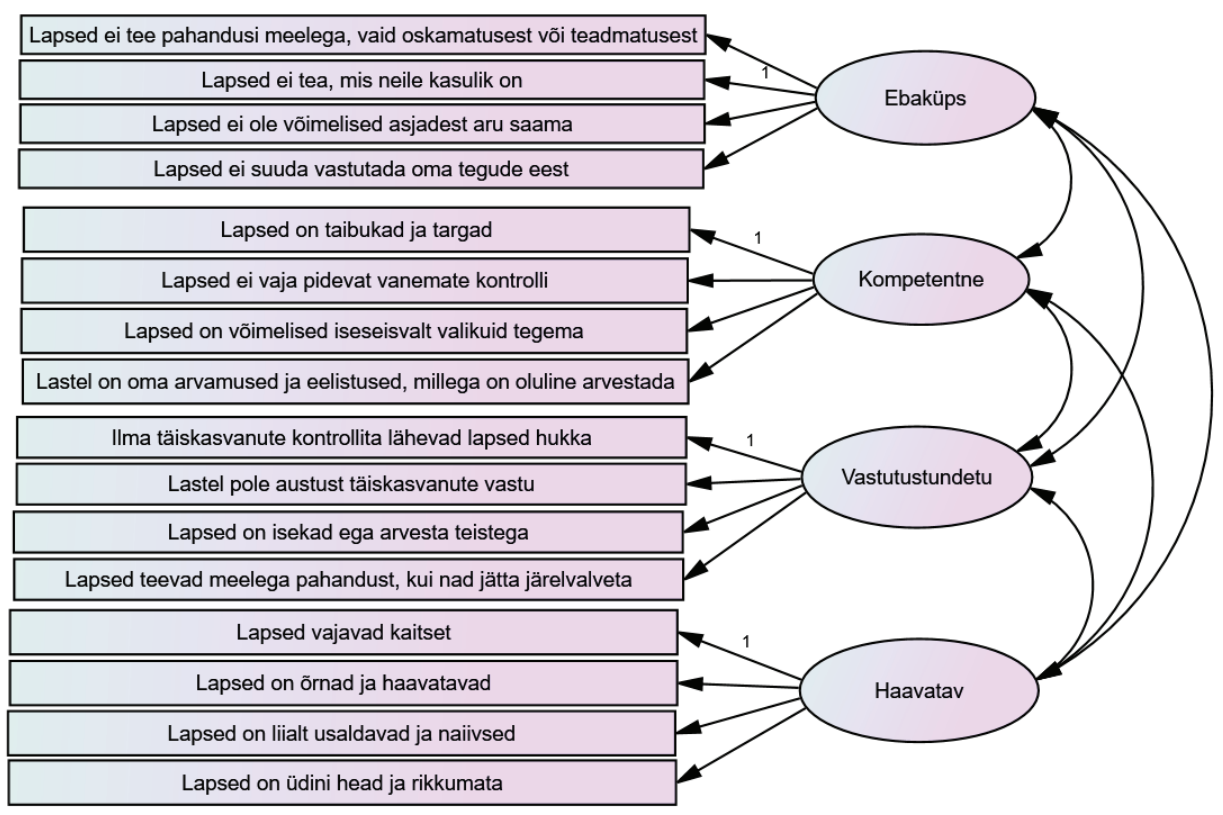

Joonis 1. Lapse kuvandeid mõotvad väited ja lapse kuvandid "Lapse õiguste ja vanemluse uuringu” (Anniste et al. 2018) operatsionaliseeritud mudelis. 
Uuringuga küsitleti 1110 last 4.-11. klassist, vanuserühmas $10-17^{1}$ ja 1248 täiskasvanut vanuses 18-74 aastat. Mõlemad valimid olid vastava vanusrühma osas esinduslikud. Andmeid kaaluti laste puhul soo, kooliastme ja piirkonna lõikes ning täiskasvanute puhul vanuse, soo, piirkonna, rahvuse, haridustaseme ja lapse olemasolu² lõikes (vt täpsemalt Koppel et al. 2018). Kaalutud ja kaalumata valimi suurused on esitatud tabelis 1 .

Täiskasvanud vastajate valimi puhul seati eesmärgiks, et pooltel (50\%) vastanutest oleks alla 18aastane laps või lapsed, sest mitmed uuringuküsimused puudutasid laste kasvatamist ja lapsevanemaks olemist. Lõplikus valimis moodustasid alla 18aastaste lastega vanemad 48\% kõigist vastanutest ( $\mathrm{N}=596)$. Seega annab uuringuandmestik võimaluse võrrelda täiskasvanute valimi sees omakorda alla 18aastaste lastega täiskasvanute hoiakuid täiskasvanutega, kel pole alla 18aastasi lapsi.

Täpsema ülevaate uuringu korraldamisest ja küsitluse läbiviimisest leiab huviline uuringumetoodika aruandest (Koppel et al. 2018).

Lapse kuvandi uurimiseks esitati 16 väidet, mille puhul paluti vastajatel öelda, mil määral nad väidetega nõustuvad. Kuna laste valimis kasutati kahte erinevat ankeeti, milles noorema kooliastme õpilaste (4.-6. klass) käest küsiti kuvandiga seoses vähem küsimusi kui vanemate kooliastmete õpilaste (7.-11. klass) ja täiskasvanute käest, on käesolevasse analüüsi kaasatud kahe vanema kooliastme (7.-11. klassi) andmed, mida täiskasvanute vastustega võrreldakse. Seetõttu on laste valimi suuruseks siinses analüüsis 624 õpilast.

Sotsiaaldemograafiliste tunnustena, mis laste kuvanditega seostuda võiksid, vaadatakse analüüsis vastaja vanust, sugu, rahvust ning asjaolu, kas vastaja on kuulnud midagi lapse õigustest. Kuna varasemad uuringud on näidanud nii soo kui ka rahvuse mõju (nt Jõers-Türn \& Kasearu 2013; Tamm et al. 2018), vaadatakse ka käesolevas analüüsis sugu ja rahvust kui kultuurilist mõju peegeldavaid tunnuseid. Siinkohal on oluline märkida, et analüüsis on vene rahvus liidetud muude rahvustega ning tähistatud üldnimetusega "muu", kuigi on teada, et peamiselt on selles grupis vene rahvuse esindajad.

See, kas vastaja on kuulnud lapse õigustest, võiks eelduslikult mõjutada seda, kuivõrd kompetentsena lapsi nähakse. Näiteks olen leidnud, et laste kaasamist toetavad ühiskondlikud hoiakud on muuhulgas seotud ka sellega, kas vastaja on kuulnud lapse õigustest või mitte (Reinomägi 2020). Need, kes küsitlusele vastates väitsid, et nad ei tea, kas nad on lapse õigustest kuulnud, on siinses analüüsis liidetud nendega, kes pole lapse õigustest kuulnud.

Täiskasvanute puhul vaadatakse kuvandite erinevust ka vastaja haridustaseme lõikes ning selle järgi, kas vastaja on alla 18aastase lapse vanem või mitte. Kuna need täiskasvanud, kes on alaealiste lastega seotud, võivad oma vahetu kogemuse tõttu lapsi teisiti näha kui need, kes vahetult alaealiste 
lastega seotud ei ole, on selle asjaolu arvestamine laste kuvandi puhul kindlasti asjakohane.

Kõigil vastajatel paluti laste kuvandiga seotud väiteid hinnata neljapallisel skaalal ning märkida, kuivõrd nad esitatud väidetega nõustuvad, valides 1 , kui vastaja esitatud väitega üldse ei nõustu ning 4, kui ta on esitatud väitega täiesti nõus. Vaikimisi ${ }^{3}$ oli täiskasvanutel võimalik valida vastusevariandina ka "ei oska öelda", mida valis erinevate väidete puhul keskmiselt 2-5\% vastanutest. Võrreldavuse huvides on kõik need täiskasvanute vastused kodeeritud andmestikus puuduvateks vastusteks.

Tabel 1. Kaalutud ja kaalumata valimi suurus

\begin{tabular}{|c|c|c|c|c|c|}
\hline \multirow{2}{*}{\begin{tabular}{|l|} 
Lapsed \\
\end{tabular}} & & \multicolumn{2}{|c|}{ Kaalumata valim } & \multicolumn{2}{|c|}{ Kaalutud valim } \\
\hline & & $\mathrm{N}$ & $\%$ & $\mathrm{~N}$ & $\%$ \\
\hline \multicolumn{6}{|l|}{ Sugu } \\
\hline & Tüdrukud & 578 & $52,1 \%$ & 576 & $51,8 \%$ \\
\hline & Poisid & 532 & $47,8 \%$ & 536 & $48,2 \%$ \\
\hline \multicolumn{6}{|c|}{ Kooliaste } \\
\hline & 4.-6. klass & 453 & $40,8 \%$ & 488 & $43,9 \%$ \\
\hline & 7.-9. klass & 430 & $38,7 \%$ & 427 & $38,4 \%$ \\
\hline & 10.-11. klass & 227 & $20,5 \%$ & 197 & $17,7 \%$ \\
\hline \multicolumn{6}{|l|}{ Piirkond } \\
\hline & Põhja-Eesti & 555 & $50 \%$ & 493 & $44,3 \%$ \\
\hline & Lääne-Eesti & 87 & $7,8 \%$ & 105 & $9,4 \%$ \\
\hline & Kirde-Eesti & 124 & $11,2 \%$ & 104 & $9,4 \%$ \\
\hline & Kesk-Eesti & 95 & $8,6 \%$ & 124 & $11,2 \%$ \\
\hline & Lõuna-Eesti & 249 & $22,4 \%$ & 286 & $25,7 \%$ \\
\hline \multicolumn{6}{|c|}{ Täiskasvanud } \\
\hline \multicolumn{6}{|l|}{ Sugu } \\
\hline & Mehed & 591 & $47,0 \%$ & 599 & $49,0 \%$ \\
\hline & Naised & 657 & $53,0 \%$ & 649 & $51,0 \%$ \\
\hline \multicolumn{6}{|c|}{ Vanusjaotus } \\
\hline & 18-25aastased & 99 & $7,9 \%$ & 163 & $13,0 \%$ \\
\hline & 26-49aastased & 723 & $57,9 \%$ & 593 & $47,6 \%$ \\
\hline & 50-74aastased & 426 & $34,2 \%$ & 470 & $39,4 \%$ \\
\hline \multicolumn{6}{|l|}{ Rahvus } \\
\hline & Eestlased & 851 & $68,2 \%$ & 860 & $68,9 \%$ \\
\hline & Venelased & 326 & $26,1 \%$ & 320 & $25,7 \%$ \\
\hline & Muu kodakondsus & 71 & $5,7 \%$ & 67 & $5,4 \%$ \\
\hline \multicolumn{6}{|l|}{ Piirkond } \\
\hline & Põhja-Eesti & 547 & $43,8 \%$ & 486 & $39,0 \%$ \\
\hline & Lääne-Eesti & 145 & $11,7 \%$ & 168 & $13,5 \%$ \\
\hline & Kagu-Eesti & 127 & $10,1 \%$ & 145 & $11,7 \%$ \\
\hline
\end{tabular}




\begin{tabular}{|l|l|l|l|l|l|}
\hline & Kesk-Eesti & 116 & $9,3 \%$ & 132 & $10,6 \%$ \\
\hline & Lõuna-Eesti & 313 & $25,1 \%$ & 313 & $25,2 \%$ \\
\hline Haridus & & & & & \\
\hline & Alg- või põhiharidus & 41 & $3,3 \%$ & 131 & $10,5 \%$ \\
\hline & $\begin{array}{l}\text { Kesk-, kutse-, kesk- } \\
\text { eriharidus }\end{array}$ & 614 & $49,2 \%$ & 759 & $60,9 \%$ \\
\hline & Kõrgharidus & 593 & $47,5 \%$ & 375 & $28,6 \%$ \\
\hline $\begin{array}{l}\text { Alaealise lapse } \\
\text { olemasolu }\end{array}$ & Jah & & & & \\
\hline & $\mathrm{Ei}$ & 596 & $48,2 \%$ & 587 & $47,7 \%$ \\
\hline & 643 & $51,8 \%$ & 651 & $52,3 \%$ \\
\hline
\end{tabular}

Lapse kuvandiga seotud hoiakute jaotusest parema ülevaate saamiseks esitatakse käesolevas analüüsis laste ja täiskasvanute hinnangud esmalt sagedusjaotustena, mis on reastatud vastusevariandi "täiesti nõus" alusel (joonis 2). Selleks, et uurida, millised kuvandid laste ja täiskasvanute hulgas uuringuandmete alusel moodustuvad, kasutatakse eksploratiivset ehk otsingulist (vt ka Tooding 2014) faktoranalüüsi, mida siinses töös on nimetatud uurimuslikuks faktoranalüüsiks. Selline analüüsisamm valiti seetõttu, et teoorias väljatoodud lapse kuvandid (joonis 1 ) viitavad küll ühele või teisele hoiakute komplektile, kuid käesoleva analüüsi aluseks olevate andmete puhul soovitakse esmalt vaadata, kuidas uuringus esitatud väited Eesti laste ja täiskasvanute puhul koonduvad ja millised kuvandid nende pinnalt moodustuvad. Sel moel koondatakse uuringus esindatud 16 väidet kitsamateks lapse kuvanditeks ja kirjeldatakse selle käigus moodustunud faktoreid, andes neile sisuga seotud nimetused (tabelid 2 ja 4). Teoreetilist kuvandite mudelit (joonis 1) aluseks võttes, viiakse läbi kinnitav faktoranalüüs, et vastata küsimusele, kas teoreetiline mudel sobib lapse kuvandeid kirjeldama laste ja täiskasvanute hoiakuid aluseks võttes või leidub selleks mõni parem mudel (tabelid 3 ja 5, joonis 3). Üldistatud lineaarsete mudelite abil (GLM univariate) kirjeldatakse, kuivõrd eristub keskmine üht või teist kuvandit peegeldava faktori väärtus ühes või teises sotsiaalses grupis (tabel 6). Viimast tehakse täiskasvanute andmestiku näitel. Analüüsis kasutatud andmed on kaalutud ning andmeanalüüs ja andmetöötlus on toimunud analüüsipaketi SPSS, AMOS ja Excel abil.

\section{Toetus erinevatele lapse kuvandeid kirjeldavatele väidetele}

"Lapse õiguste ja vanemluse uuringus" (2018) paluti vastajatel hinnata, kuivõrd nad nõustuvad laste olemust kirjeldavate erinevate väidetega. Laste ja 
täiskasvanute vastused on esitatud joonisel 2. Selgub, et erinevaid väiteid toetavad lapsed ja täiskasvanud erinevalt ning seda erinevust võib pidada ka statistiliselt oluliseks (vt selgitus joonise 2 juures). On väiteid, mida toetavad lapsed enam kui täiskasvanud ning vastupidi.

Asjaolu, et lastega (54\%) võrreldes näeb märkimisväärselt suurem osa täiskasvanutest (71\%) lapsi kui kedagi, kes vajavad kaitset, viitab Eesti ühiskonnas domineerivale haavatava lapse kuvandile. Eelöeldut toetab ka see, et suur osa täiskasvanutest nõustub väitega, et lapsed on õrnad ja haavatavad: $39 \%$ täiskasvanutest nõustub sellega täielikult, samas lastest nõustub selle väitega täielikult vaid $16 \%$.

Hoiakutest paistab välja ka täiskasvanute suhtumine lastesse kui kellessegi, kes on (veel) teadmatuses ega oska alati õigesti käituda. Nii leidsid täiskasvanute hulgas lastega võrreldes rohkem poolehoidu väited, mis peegeldavad lapsi kui inimesi, kes peavad alles õppima ja arenema. Näiteks väitega, et lapsed ei tee pahandusi meelega, vaid oskamatusest või teadmatusest, nõustub $26 \%$ täiskasvanutest täielikult, samas kui lastest nõustub selle väitega vaid $11 \%$. Veerand täiskasvanutest nõustub täielikult ka sellega, et lapsed ei tea, mis neile kasulik on, samas kui laste puhul toetab seda seisukohta täielikult vaid kümnendik.

Mõnevõrra vähem oli neid täiskasvanuid (19\%), kes leiavad, et lapsed on liialt usaldavad ja naiivsed, ning et lapsed on üdini head ja rikkumata ( $16 \%$ täiskasvanutest nõustus täiesti). Lapsed ise toetavad kahte viimast väidet tunduvalt vähem (11\% toetab väidet, et lapsed on liialt usaldavad ja naiivsed ning $7 \%$ väidet, et lapsed on üdini head ja rikkumata). Väitega, et lapsed ei ole võimelised asjadest aru saama, nõustuvad aga ühtviisi vähe nii lapsed (7\%) kui täiskasvanud (9\%).

Võib öelda, et Eesti ühiskonnas nähakse lapsi kompetentsetena. Sealjuures on aga tähelepanuväärne, et väide "Lapsed on taibukad ja targad", leidis oluliselt suuremat poolehoidu täiskasvanute hulgas: sellega nõustub täielikult $22 \%$ lastest, samas täiskasvanutest nõustub selle väitega täielikult koguni $47 \%$. Seega usuvad täiskasvanud laste taibukusse enam kui lapsed ise. Lapse õiguste põhimõtteid toetava väitega, et lastel on oma arvamused ja eelistused, millega on oluline arvestada, on nii lapsed kui ka täiskasvanud ühel meelel ja seda toetab kuus vastajat kümnest. Erinevalt täiskasvanutest näevad lapsed lapsi oluliselt iseseisvamatena. Suur osa lastest (24\%) nõustub täielikult väitega, et lapsed on võimelised iseseisvalt valikuid tegema, täiskasvanutest nõustub täielikult selle väitega ligi kümnendik vähem (16\%).

Vastutustundetu lapse kuvandiga seotud kontrolli rõhutavate väidete puhul lahknevad laste ja täiskasvanute hinnangud samuti. Kui $28 \%$ täiskasvanutest nõustub täielikult väitega, et ilma täiskasvanute kontrollita lähevad lapsed huk$\mathrm{ka}$, siis lastest toetab seda seisukohta vaid 17\%. Samas on neid, kes leiavad, et 
lapsed ei vaja pidevat vanemate kontrolli, nii laste kui ka täiskasvanute hulgas üsna vähe: seda väidet toetab täiesti $14 \%$ lastest ja kõigest $7 \%$ täiskasvanutest.

Ühtviisi vähe toetavad lapsed ja täiskasvanud väiteid, et lapsed ei suuda vastutada oma tegude eest ning et lapsed teevad meelega pahandust, kui nad järelevalveta jätta. Ka väiteid, et lastel pole austust täiskasvanute vastu, lapsed on isekad ega arvesta teistega, toetatakse vähe. Eelnimetatud nelja väite puhul on toetajaid nii laste kui ka täiskasvanute hulgas 4-7\%.

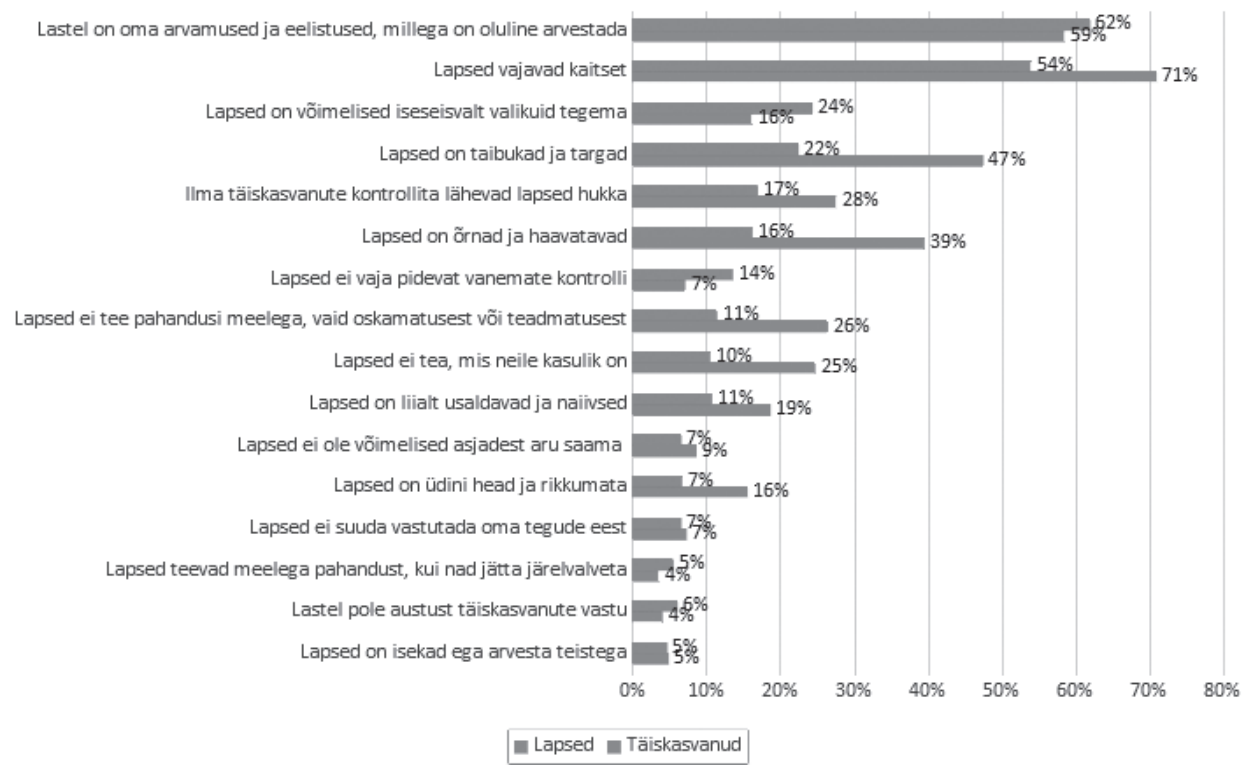

Joonis 2. Erinevaid laste kuvandeid iseloomustavate väidete toetus laste ja täiskasvanute hulgas vastusevariandi "Täiesti nõus" alusel".

\section{Lapse kuvandid laste hulgas ja nende kandjate iseloomustus}

Lapse kuvandite kirjeldamiseks teostati laste ja täiskasvanute antud hinnangute põhjal esmalt uuringus esitatud väiteid koondav uurimuslik faktoranalüüs. Selle käigus joonistus nii laste kui ka täiskasvanute vastustest välja neli eristuvat kuvandit, mis hõlmavad laste ja täiskasvanute puhul erinevaid küsimustikus esitatud väiteid. Laste puhul moodustunud kuvandid on esitatud tabelis 2 . 
Tabel 2. Laste hinnangute põhjal uurimusliku faktoranalüüsi käigus moodustunud lapse kuvandid ja nende aluseks olevad väited

\begin{tabular}{|c|c|c|c|c|}
\hline & \multicolumn{4}{|c|}{ Lapse kuvandid } \\
\hline & $\begin{array}{l}\text { Faktor } 1 \\
\text { Isekad ja } \\
\text { vastutus- } \\
\text { tundetud }\end{array}$ & \begin{tabular}{|l|} 
Faktor 2 \\
Kompe- \\
tentsed ja \\
iseseisvad
\end{tabular} & $\begin{array}{l}\text { Faktor } 3 \\
\text { Haavatavad, } \\
\text { kaitset ja } \\
\text { kontrolli } \\
\text { vajavad, oma } \\
\text { arvamusega }\end{array}$ & $\begin{array}{l}\text { Faktor } 4 \\
\text { Süütud } \\
\text { ja eba- } \\
\text { küpsed }\end{array}$ \\
\hline $\begin{array}{l}\text { Lapsed on isekad ega arvesta } \\
\text { teistega }\end{array}$ &, 790 &,- 055 &,- 003 &,- 070 \\
\hline $\begin{array}{l}\text { Lastel pole austust } \\
\text { täiskasvanute vastu }\end{array}$ &, 729 &,- 074 &,- 037 &,- 123 \\
\hline $\begin{array}{l}\text { Lapsed teevad meelega } \\
\text { pahandust, kui nad jätta } \\
\text { järelevalveta }\end{array}$ & ,624 &,- 075 & ,046 &, 123 \\
\hline $\begin{array}{l}\text { Lapsed on liialt usaldavad ja } \\
\text { naiivsed }\end{array}$ & ,499 &,- 147 & ,437 & ,249 \\
\hline $\begin{array}{l}\text { Lapsed ei suuda vastutada } \\
\text { oma tegude eest }\end{array}$ & ,388 &,- 341 & ,273 & ,320 \\
\hline $\begin{array}{l}\text { Lapsed on võimelised } \\
\text { iseseisvalt valikuid tegema }\end{array}$ &,- 117 &, 722 &,- 098 &, 039 \\
\hline $\begin{array}{l}\text { Lapsed ei vaja pidevat } \\
\text { vanemate kontrolli }\end{array}$ & ,111 &, 650 &,- 313 &, 034 \\
\hline Lapsed on taibukad ja targad &,- 281 &, 547 & ,262 &, 160 \\
\hline Lapsed vajavad kaitset &,- 073 &,- 107 &, 793 &,- 011 \\
\hline $\begin{array}{l}\text { Lapsed on õrnad ja } \\
\text { haavatavad }\end{array}$ & ,227 &,- 058 & ,661 & ,217 \\
\hline $\begin{array}{l}\text { Lastel on oma arvamused ja } \\
\text { eelistused, millega on oluline } \\
\text { arvestada }\end{array}$ &,- 309 & ,421 & ,480 &, 003 \\
\hline $\begin{array}{l}\text { Ilma täiskasvanute } \\
\text { kontrollita lähevad lapsed } \\
\text { hukka }\end{array}$ & ,442 &,- 327 & ,446 &,- 042 \\
\hline $\begin{array}{l}\text { Lapsed on üdini head ja } \\
\text { rikkumata }\end{array}$ &,- 021 & , 100 & ,006 &, 765 \\
\hline $\begin{array}{l}\text { Lapsed ei tee pahandusi } \\
\text { meelega, vaid oskamatusest } \\
\text { või teadmatusest }\end{array}$ &,- 085 & ,112 & ,120 &, $\mathbf{5 9 1}$ \\
\hline $\begin{array}{l}\text { Lapsed ei ole võimelised } \\
\text { asjadest aru saama }\end{array}$ & ,478 &,- 373 &,- 039 &, 504 \\
\hline $\begin{array}{l}\text { Lapsed ei tea, mis neile } \\
\text { kasulik on }\end{array}$ & ,375 &,- 421 & , 109 &, 437 \\
\hline Kirjeldusaste & $17 \%$ & $30 \%$ & $42 \%$ & $53 \%$ \\
\hline
\end{tabular}

Peakomponentide analüüs Varimax pööramismeetodil Kaiseri normalisatsiooniga.

Kaiser-Meyer-Olkini (KMO) testi väärtus 0,819; Bartletti testi väärtus 2099,6; vabadusastmete arv (Df) 120, mudel on statistiliselt oluline (olulisuse nivool 0,01 on vastav väärtus 0,00). 
Selgub, et laste vastuste põhjal moodustunud kuvandid erinevad mõnevõrra teoreetilises mudelis esitatud väidete jaotusest. Nimetagem esimest uuringulise faktoranalüüsiga moodustunud kuvandit lastest tinglikult "Isekad ja vastutustundetud". Sellesse kuvandisse paigutub viis väidet, millest vaid osa vastab teoreetilise mudeli vastutustundetu lapse kuvandile. Näiteks paigutuvad siia ka väited "Lapsed on liialt usaldavad ja naiivsed" ning "Lapsed ei suuda vastutada oma tegude eest". Neist esimene sobituks faktorlaadungi poolest ka kolmandasse jaotusse, kirjeldades teoreetilise käsitluse kohaselt haavatava lapse kuvandit. Teise väite puhul nähtub faktorlaadungi suunamärgist, et see on vastupidine teisele kuvandile, mis siinses mudelis on nimetatud tinglikult "Kompetentsed ja iseseisvad".

Väide "Ilma täiskasvanute kontrollita lähevad lapsed hukka", mis teoreetilises mudelis kirjeldas vastutustundetu lapse kuvandit, paigutub laste hinnangute alusel uurimusliku faktoranalüüsi mudelis hoopiski kolmandasse faktorisse ("Haavatavad, kaitset ja kontrolli vajavad, oma arvamusega"), kuigi on näha, et tegelikult sobituks see faktorlaadungi poolest ka esimese kuvandiga.

Laste väidete alusel moodustunud teine kuvand on siin nimetatud kui "Kompetentsed ja iseseisvad" ning sobitub sisu poolest teoreetilise mudeli kompetentse lapse kuvandiga, välja arvatud selle erandiga, et leitud mudelis puudub väide "Lastel on oma arvamused ja eelistused, millega on oluline arvestada", mis kuulus teoreetilises mudelis kompetentse kuvandi juurde. Kõnealune väide paigutub uurimusliku faktoranalüüsi mudelis hoopiski kolmandasse faktorisse, mille järgi võib lapsi pidada haavatavateks, kaitset ja kontrolli vajavateks, kuid siiski oma arvamuste ja eelistustega grupiks.

Kolmas kuvand, mis uurimusliku faktoranalüüsi abil moodustus, on siin tinglikult nimetatud "Haavatavad, kaitset ja kontrolli vajavad, oma arvamusega". Üldiselt sobivad sellesse kuvandisse koondunud väited teoreetilises mudelis välja toodud haavatava lapse kuvandiga, kuid teoreetilises kuvandis kuulusid haavatava lapse kuvandi hulka ka väited "Lapsed on liialt usaldavad ja naiivsed" ning "Lapsed on üdini head ja rikkumata", mis otsingulise faktoranalüüsi tulemusel koondunud kuvandisse pigem ei kuulu. Nende asemel on siin väited "Lastel on oma arvamused ja eelistused, millega on oluline arvestada" ja "Ilma täiskasvanute kontrollita lähevad lapsed hukka".

Neljas uurimusliku faktoranalüüsiga moodustunud lapse kuvand on nimetatud "Süütud ja ebaküpsed".

Eelöeldu põhjal on selge, et mitmed tunnused võivad kuuluda nii ühe kui ka teise kuvandi juurde. Seetõttu teostati moodustunud kuvandite osas kinnitav faktoranalüüs (võttes arvesse väärtuse poolest nii ühe kui teise kuvandiga sobivaid faktorlaadungeid), et iseloomustada laste hoiakute seoseid erinevate kuvanditega. Mudelite sobivusindeksina arvestati RMSEA (ingl root mean 
square error of approximation) ja CFI (ingl Comparative fit index) väärtust. Mudelit võib pidada heaks, kui RMSEA väärtus jääb alla 0,08 ja CFI on 0,90 või suurem (Byrne 2016). Kui RMSEA väärtus ületab 0,08, ei saa viga enam lubatavaks pidada (Brown 2006).

Tabelis 3 on esitatud kinnitava faktoranalüüsi käigus moodustunud mudelite sobivusindeksid laste andmete osas.

Tabel 3. Laste andmete alusel moodustatud kinnitava faktoranalüüsi mudelite sobivusindeksid

\begin{tabular}{|l|l|l|}
\hline Mudel & RMSEA & CFI \\
\hline Teoreetilisest mudelist lähtuv kinnitav faktoranalüüs & 0,09 & 0,80 \\
\hline Uurimusliku faktoranalüüsi käigus moodustatud mudel & 0,10 & 0,70 \\
\hline
\end{tabular}

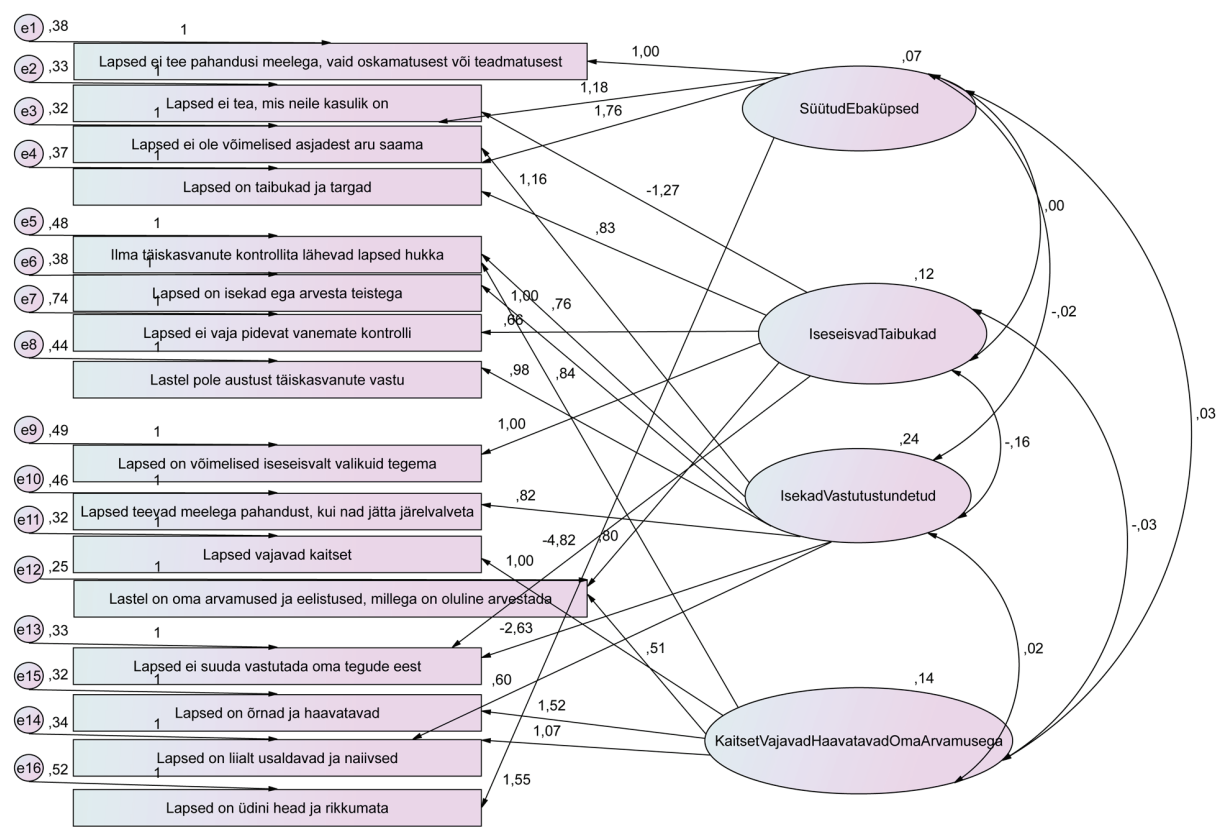

Joonis 3. Laste hoiakute jaotus lapse kuvanditeks.

Tabelis 3 esitatud näitajate alusel võib öelda, et kumbagi mudelit ei saa pidada kuigi heaks. Seetõttu prooviti lähtuvalt uurimusliku faktoranalüüsi käigus tekkinud faktorlaadungite jaotustest (tabel 2) luua uus mudel. Tulemus on esitatud joonisel 3. Loodud mudeli puhul on RMSEA väärtus 0,07 ja CFI väärtus 0,90 . 
Seega võib öelda, et teoreetilises mudelis esitatud väidete jaotus ei ole laste hinnangute kirjeldamiseks kõige parem, ning lapsed näevad lapsi mõnevõrra teisiti kui täiskasvanute poolt välja pakutud teoreetiline mudel.

Üheks analüüsiülesandeks oli vaadata, kuidas eristuvad lapse kuvandid sotsiaaldemograafiliste tunnuste alusel. Kuna aga laste andmete näitel ei osutunud teoreetiline mudel kinnitava faktoranalüüsi käigus heaks ning tegelikult jaotusid kuvandite aluseks olevad väited mitme erineva kuvandi vahel, on keeruline seostada sotsiaaldemograafiliste tunnuste kirjeldust moodustunud kuvanditega, mistõttu jääb see eesmärk edaspidisteks analüüsideks.

\section{Lapse kuvandid täiskasvanute hulgas ja nende kandjate iseloomustus}

Sarnaselt laste andmetele analüüsiti ka täiskasvanute andmeid. Täiskasvanute puhul koondusid uurimusliku faktoranalüüsi käigus laste kuvandi kohta esitatud väited samuti nelja faktorisse (vt tabel 4), kuid laste andmete pinnalt moodustunud kuvanditest on need mõnevõrra erinevad.

Tabel 4. Täiskasvanute hinnangute põhjal uurimusliku faktoranalüüsi käigus moodustunud lapse kuvandid ja nende aluseks olevad väited

\begin{tabular}{|l|l|l|l|l|}
\hline \multicolumn{4}{|l|}{ Lapse kuvandid } \\
\hline & $\begin{array}{l}\text { Faktor 1 } \\
\text { Isekad, } \\
\text { vastutus- } \\
\text { tundetud } \\
\text { ja eba- } \\
\text { küpsed }\end{array}$ & $\begin{array}{l}\text { Faktor 2 } \\
\text { Kompe- } \\
\text { tentsed, } \\
\text { kuid } \\
\text { kaitset } \\
\text { vajavad }\end{array}$ & $\begin{array}{l}\text { Faktor 3 } \\
\text { Haava- } \\
\text { tavad, } \\
\text { naiivsed, } \\
\text { süütud }\end{array}$ & $\begin{array}{l}\text { Faktor 4 } \\
\text { Ise- } \\
\text { seisvad }\end{array}$ \\
\hline $\begin{array}{l}\text { Lapsed on isekad ega arvesta } \\
\text { teistega }\end{array}$ & $\mathbf{, 7 6 1}$ &,- 193 &,- 050 &, 085 \\
\hline $\begin{array}{l}\text { Lapsed teevad meelega } \\
\text { pahandust, kui nad jätta } \\
\text { järelvalveta }\end{array}$ & $\mathbf{, 6 7 7}$ &,- 030 &, 071 &,- 067 \\
\hline $\begin{array}{l}\text { Lastel pole austust } \\
\text { täiskasvanute vastu }\end{array}$ & $\mathbf{, 5 9 9}$ &,- 324 &,- 127 &,- 048 \\
\hline $\begin{array}{l}\text { Lapsed ei ole võimelised asjadest } \\
\text { aru saama }\end{array}$ & $\mathbf{, 5 6 4}$ &,- 178 &, 362 &,- 104 \\
\hline Lapsed ei tea, mis neile kasulik on & $\mathbf{, 5 0 9}$ &, 042 &, 238 &,- 286 \\
\hline $\begin{array}{l}\text { Lastel on oma arvamused ja } \\
\text { eelistused, millega on oluline } \\
\text { arvestada }\end{array}$ &,- 164 &, $\mathbf{7 5 9}$ &, 029 &, 120 \\
\hline Lapsed vajavad kaitset &,- 026 &, $\mathbf{6 8 7}$ &, 153 &,- 287 \\
\hline
\end{tabular}




\begin{tabular}{|l|l|l|l|l|}
\hline \multicolumn{4}{|l|}{ Lapse kuvandid } \\
\hline Lapsed on taibukad ja targad &,- 170 & $\mathbf{6 7 1}$ &, 061 &, 202 \\
\hline $\begin{array}{l}\text { Lapsed on liialt usaldavad ja } \\
\text { naiivsed }\end{array}$ &, 217 &, 074 &, $\mathbf{6 8 8}$ &,- 106 \\
\hline $\begin{array}{l}\text { Lapsed on üdini head ja } \\
\text { rikkumata }\end{array}$ &,- 149 &, 230 & $\mathbf{, 6 8 5}$ &, 089 \\
\hline $\begin{array}{l}\text { Lapsed ei suuda vastutada oma } \\
\text { tegude eest }\end{array}$ &, 177 &,- 232 & $\mathbf{, 6 3 6}$ &,- 114 \\
\hline Lapsed on õrnad ja haavatavad &,- 015 &, 401 & $\mathbf{, 5 7 2}$ &,- 205 \\
\hline $\begin{array}{l}\text { Lapsed ei tee pahandusi } \\
\text { meelega, vaid oskamatusest või } \\
\text { teadmatusest }\end{array}$ &,- 306 &, 218 &, $\mathbf{3 1 4}$ &, 012 \\
\hline $\begin{array}{l}\text { Lapsed ei vaja pidevat vanemate } \\
\text { kontrolli }\end{array}$ &, 036 &,- 053 &,- 110 & $\mathbf{, 8 0 0}$ \\
\hline $\begin{array}{l}\text { Lapsed on võimelised iseseisvalt } \\
\text { valikuid tegema }\end{array}$ &,- 161 &, 292 &,- 049 & $\mathbf{, 6 6 0}$ \\
\hline $\begin{array}{l}\text { Ilma täiskasvanute kontrollita } \\
\text { lähevad lapsed hukka }\end{array}$ &, 492 &, 208 &, 019 & $\mathbf{- , 4 9 3}$ \\
\hline Kirjeldusaste & $\mathbf{1 6 \%}$ & $29 \%$ & $42 \%$ & $52 \%$ \\
\hline
\end{tabular}

Peakomponentide analüüs Varimax pööramismeetodil Kaiseri normalisatsiooniga. Kaiser-Meyer-Olkini (KMO) testi väärtus 0,786; Bartletti testi väärtus 3173,6; vabadusastmete arv (Df) 120, mudel on statistiliselt oluline (olulisuse nivool 0,01 on vastav väärtus 0,00).

Esimene moodustunud kuvand kannab tinglikku nimetust "Isekad, vastutustundetud ja ebaküpsed", hõlmates kolme esimese väitega teoreetilise mudeli vastutustundetu lapse kuvandi väiteid, kuid nende kõrval koonduvad kuvandisse ka teoreetilise mudeli ebaküpse lapse kuvandi kaks väidet (lapsed ei ole võimelised asjadest aru saama; lapsed ei tea, mis neile kasulik on). Teoreetilise mudeli vastutustundetu lapse kuvandi neljas väide ("Ilma täiskasvanute kontrollita lähevad lapsed hukka") võib täiskasvanute puhul uurimusliku faktoranalüüsi laadungite järgi paigutuda nii esimesse kui ka viimasesse, lapsi iseseisvaks tunnistavasse kuvandisse.

Teise kuvandisse, mille nimetuseks on "Kompetentsed, kuid kaitset vajavad", paigutuvad teoreetilise mudeli kompetentse kuvandi kaks väidet (lastel on oma avamused ja eelistused, millega on oluline arvestada; lapsed on taibukad ja targad) ning lisaks neile ka teoreetilise mudeli haavatava kuvandi väide "Lapsed vajavad kaitset".

Kolmandasse kuvandisse, mis uurimusliku faktoranalüüsi alusel moodustub, koondub viis väidet. Kolm nendest sobituvad teoreetilise mudeli haavatava lapse kuvandiga (lapsed on liialt usaldavad ja naiivsed; lapsed on üdini head ja rikkumata; lapsed on õrnad ja haavatavad), ülejäänud kaks aga teoreetilise 
mudeli ebaküpse lapse kuvandiga (lapsed ei suuda vastutada oma tegude eest; lapsed ei tee pahandusi meelega, vaid oskamatusest või teadmatusest). Seetõttu kannab kolmas täiskasvanute andmete alusel moodustunud kuvand tinglikku nimetust "Haavatavad, naiivsed ja süütud".

Neljanda moodustunud kuvandi nimetuseks on "Iseseisvad" ja see hõlmab teoreetilise mudeli kompetentse lapse kuvandi kahte väidet (lapsed ei vaja pidevat vanemate kontrolli; lapsed on võimelised iseseisvalt valikuid tegema) ning sisult ümberpööratuna väidet "Ilma täiskasvanute kontrollita lähevad lapsed hukka". Ehk siis kinnitavad need väited kõik, et lapsed on võimelised ise otsuseid langetama.

Võib öelda, et kui laste hoiakute puhul esines kuus sellist väidet, mis faktorlaadungeid arvesse võttes võisid paigutuda nii ühte kui ka teise moodustunud kuvandisse, siis täiskasvanute puhul oli selliseid väiteid kaks. Väide, mis nii laste kui täiskasvanute puhul üsna võrdväärselt erinevate kuvandite alla oleks sobitunud, on "Ilma täiskasvanute kontrollita lähevad lapsed hukka".

Seetõttu teostati ka täiskasvanute andmestiku alusel kinnitav faktoranalüüs, et võrrelda teoreetilise mudeli ja uurimusliku faktoranalüüsi alusel tekkinud mudeli headust ning vaadata kolmandana mudelit, kus enam-vähem võrdsete faktorlaadungitega väited on mitme kuvandi vahel jaotatud. Tabelis 5 on toodud täiskasvanute andmete pinnalt kinnitava faktoranalüüsi käigus moodustunud mudelite sobivusindeksid.

Tabel 5. Täiskasvanute andmete alusel moodustatud kinnitava faktoranalüüsi mudelite sobivusindeksid

\begin{tabular}{|l|l|l|}
\hline Mudel & RMSEA & CFI \\
\hline Teoreetilisest mudelist lähtuv kinnitav faktoranalüüs & 0,08 & 0,74 \\
\hline Uurimusliku faktoranalüüsi käigus moodustatud mudel & 0,16 & 0,05 \\
\hline
\end{tabular}

Tabelis 5 esitatud näitajate põhjal võib öelda, et pigem võib heaks pidada teoreetilist mudelit. Laste mudelite eeskujul prooviti lähtuvalt uurimusliku faktoranalüüsi käigus tekkinud faktorlaadungite jaotustest (tabel 4) luua ka uus mudel, kuid kuna selle puhul on RMSEA väärtus samuti 0,16 ja CFI väärtus 0,10 , saab tõdeda, et teoreetiline mudel sobib täiskasvanute hoiakute alusel laste kuvandeid kirjeldama.

Selleks, et vaadata, kuidas lapse kuvandid täiskasvanute puhul sotsiaaldemograafiliste tunnuste alusel eristuvad, kirjeldatakse teoreetilisest mudelist lähtuvalt üldistatud lineaarsete mudelite abil, kuivõrd keskmine üht või teist kuvandit peegeldava faktori väärtus ühes või teises sotsiaalses grupis eristub (tabel 6). 
Tabel 6. Lapse kuvandeid peegeldavate faktorite väärtuste erinevused erinevates sotsiaalsetes gruppides täiskasvanute näitel

\begin{tabular}{|c|c|c|c|c|c|c|c|c|c|}
\hline & & \multicolumn{2}{|c|}{$\begin{array}{l}\text { 1. kuvand } \\
\text { Ebaküps }\end{array}$} & \multicolumn{2}{|c|}{$\begin{array}{l}\text { 2. kuvand } \\
\text { Haavatav }\end{array}$} & \multicolumn{2}{|c|}{$\begin{array}{l}\text { 3. kuvand } \\
\text { Vastutus- } \\
\text { tundetu }\end{array}$} & \multicolumn{2}{|c|}{$\begin{array}{l}\text { 4. kuvand } \\
\text { Kompe- } \\
\text { tentne }\end{array}$} \\
\hline & & B & $\mathrm{p}$ & $\mathrm{B}$ & $\mathrm{p}$ & B & $\mathrm{p}$ & B & $\mathrm{p}$ \\
\hline $\begin{array}{l}\text { Sugu } \\
\text { (taustakategooria } \\
\text { = naine) }\end{array}$ & Mees & 0,22 & 0,07 & $-0,30$ & 0,01 & 0,63 & 0,00 & $-0,25$ & 0,02 \\
\hline $\begin{array}{l}\text { Rahvus } \\
\text { (taustakategooria } \\
=\text { muu) }\end{array}$ & Eestlane & $-1,10$ & 0,00 & $-0,52$ & 0,00 & $-0,90$ & 0,00 & 0,32 & 0,01 \\
\hline $\begin{array}{l}\text { Kas on } \\
\text { alaealisi lapsi } \\
\text { (taustakategooria } \\
=\text { ei) }\end{array}$ & Jah & $-0,47$ & 0,00 & 0,27 & 0,02 & $-0,90$ & 0,00 & 0,10 & 0,38 \\
\hline \multirow[t]{2}{*}{$\begin{array}{l}\text { Haridustase } \\
\text { (taustakategooria } \\
\text { = kõrgharidus) }\end{array}$} & $\begin{array}{l}\text { Alg- ja } \\
\text { põhi- } \\
\text { haridus }\end{array}$ & $-0,20$ & 0,55 & $-0,37$ & 0,26 & 1,27 & 0,00 & $-0,65$ & 0,04 \\
\hline & $\begin{array}{l}\text { Kesk-, } \\
\text { kutse-ja } \\
\text { keskeri- } \\
\text { haridus }\end{array}$ & 0,06 & 0,61 & $-0,12$ & 0,30 & 0,20 & 0,16 & $-0,14$ & 0,23 \\
\hline $\begin{array}{l}\text { Kas on kuulnud } \\
\text { lapse õigustest } \\
\text { (taustakategooria } \\
=\text { ei, ei oska } \\
\text { öelda) }\end{array}$ & Jah & $-0,45$ & 0,00 & $-0,12$ & 0,41 & $-0,31$ & 0,07 & 0,27 & 0,04 \\
\hline Vanus & & 0,01 & 0,02 & 0,00 & 0,64 & $-0,00$ & 0,35 & 0,00 & 0,78 \\
\hline
\end{tabular}

$B$ - regressioonikordaja vä̈̈rtus.

p-seose statistiline olulisus olulisuse nivool 0,05.

Teoreetilisest mudelist lähtuvasse ebaküpse lapse kuvandi toetajate hulka vene rahvuse esindajatega võrreldes eestlased pigem ei kuulu. Ka need, kel on alaealised lapsed, pigem ei kuulu selle kuvandi toetajate hulka, kui neid võrrelda täiskasvanutega, kel alaealisi lapsi pole. Võrredes nendega, kes lapse õigustest kuulnud ei ole või ei oska öelda, kas nad on lapse õigustest kuulnud, lapse õigustest kuulnud inimesed pigem selle kuvandi toetajate hulka ei kuulu. Samuti võib öelda, et enam on selle kuvandi esindajaid vanemate inimeste hulgas.

Haavatava lapse kuvandi toetajate hulka kuuluvad naised enam kui mehed, vene rahvusest täiskasvanud enam kui eestlased ning pigem alaealiste laste vanemad võrreldes nende täiskasvanutega, kel alaealisi lapsi pole. 
Vastutustundetu lapse kuvandi toetajate hulka kuuluvad pigem mehed naistega võrreldes, samuti pigem vene rahvusest vastajad ning need, kel alaealisi lapsi ei ole.

Kompetentse lapse kuvandi toetajate hulka kuuluvad enam naised, eestlased ning need, kes on lapse õigustest kuulnud. Kõrgharidust omavate inimestega võrreldes ei kuulu selle kuvandi toetajate hulka alg- ja põhiharidusega inimesed.

\section{Arutelu ja kokkuvõte}

Käesoleva analüüsi eesmärk oli uurida, millisena näevad lapsi lapsed ja millisena täiskasvanud, koondada erinevad vaated ülevaatlikumateks kuvanditeks, võrrelda saadud tulemusi teoreetilise alusega ning selgitada, kuidas võiks nende erinevate kuvandite kandjaid iseloomustada.

Analüüsitulemused näitavad, et "Lapse õiguste ja vanemluse uuringus" (2018) esitatud väidete alusel joonistuvad laste ja täiskasvanute puhul välja mõnevõrra erineva sisuga kuvandid. Esitatud väidete alusel saab Eesti laste hinnangute puhul tuua välja neli moodustunud lapse kuvandit, mida võib kirjeldada järgmiselt: 1) lapsed kui isekad ja vastutustundetud; 2) lapsed kui kompetentsed ja iseseisvad; 3) lapsed kui haavatavad, kaitset ja kontrolli vajavad, kuid oma arvamusega, mida on oluline arvestada; 4) lapsed kui süütud ja ebaküpsed.

Laste hinnangutes nähakse lapsi seega ühelt poolt nii isekate kui ka naiivsetena, kes tegelikult on liialt usaldavad ega ole võimelised oma tegude eest vastutama. Teisalt jälle peegeldab teine laste hulgas levinud kuvand lapsi kui iseseisvaid valikuid langetada suutvaid inimesi, kes on taibukad ega vaja pidevat vanemate kontrolli. Samas on laste hinnangute alusel ühes kuvandis koos põhimõtted, et lapsed vajavad siiski täiskasvanute kaitset ja juhendamist, sest lapsed on haavatavad, kuid sealjuures on lastel omad arvamused ja eelistused, millega on oluline arvestada. Ning üks laste hoiakute alusel ilmnenud kuvand näeb lapsi kui olemuselt häid ja rikkumata, kuid kes ei tea, mis neile kasulik on ning pahandused juhtuvad just oskamatusest või teadmatusest.

Seega moodustasid uuringus kasutatud väited, mis Karu et al. (2012) ning Anniste et al. (2018) poolt olid teoorias väljatoodud käsitlustele tuginevalt mõeldud kirjeldama kindlaid lapse kuvandeid (joonis 1), Eesti laste ja täiskasvanute puhul kirjanduses väljatoodust mõnevõrra erineva sisuga hoiakute gruppe ehk kuvandeid. Võib järeldada, et lapse kuvandite mudel, mille on teoreetilise kirjanduse alusel loonud täiskasvanud, et kirjeldada lapse kuvandeid, sobib küll täiskasvanutele, kuid mitte niivõrd lastele. Lapsed näevad lapsi täiskasvanutest erinevalt ning nende hoiakud koonduvad täiskasvanute 
hulgas valitsevate kuvanditega võrreldes erinevalt: lapsed ise konstrueerivad lastest teistsuguse kuvandi kui täiskasvanud. Lapsed näevad endid iseseisvate, taibukate ja teadlikena, kel on omad arvamused, millega on oluline arvestada. Samas aga näevad nad ka seda, et lapsed vajavad kaitset ja täiskasvanute juhendamist. Nad möönavad laste teadmatust, kuid usuvad nende headusse ja rikkumatusse. Laste kuvandites lastest on koos nii täiskasvanute kirjeldatud teoreetilise mudeli kompetentse lapse kuvand kui ka haavatava lapse kuvand, samuti ebaküpse ja haavatava lapse kuvand. Seega laste hinnangutes segunevad erinevad täiskasvanute loodud kuvandid, moodustades hoopis uue sisuga kuvandeid.

See kinnitab erinevate lapsepõlve uurijate (Ben-Arieh 2008; Thompson 2014; James \& Prout 2015) seisukohti, et laste endi roll on lapsi käsitlevates uuringutes väga oluline. Seega võiks edaspidiste uuringute puhul pöörata erilist tähelepanu laste endi arvamustele ja seisukohtadele ning lähtuvalt sotsiaalkonstruktsionistlikust vaatest uurida põhjalikumalt näiteks erinevate kvalitatiivsete analüüsiviiside abil laste arusaamu lastest ja lapsepõlvest, käsitledes sealjuures ka laste suhteid täiskasvanutega.

Kollektiivsed kuvandid kujundavad laste igapäevast reaalsust ja lastega seotud uskumusi ning seeläbi ka inimeste käitumist. Käesoleva analüüsi puhul saab öelda, et see, millisena lapsi nähakse, on täiskasvanute hulgas seotud vastaja soo ja rahvusega, aga ka sellega, kas vastajal endal on alaealisi lapsi või kas ta on kuulnud lapse õigustest. Tulemustest võib järeldada, et kultuuriline kontekst on laste kuvandiga olulisel määral seotud. Ka haridusel on oluline roll - nii näevad kõrgharidusega inimesed lapsi pigem kompetentsetena. Huvitav on täiskasvanute hoiakute analüüsist välja tuua asjaolu, et see, millisena lapsi nähakse, sõltub sellest, kas vastaja on lapse õigustest kuulnud. Lapse õigustega kursis olijad näevad lapsi pigem kompetentsetena, vähem on neid, kes peavad lapsi ebaküpseteks. Seega on lapse õiguste alane teadlikkus ja laiemalt inimõigusi puudutav haridus äärmiselt oluline, parandamaks laste võimalusi ennast ja ühiskonda laiemalt puudutavates küsimustes kaasa rääkida.

Kokkuvõtlikult võib öelda, et käesolev analüüs andis esmase ülevaate sellest, millised lapse kuvandid laste ja täiskasvanute hoiakute pinnalt joonistusid. Võib öelda, et see, millisena lapsi nähakse, on Eesti laste ja täiskasvanute hulgas erinev. Eelnevaga seoses tuleb töö ühe piirangu ja edaspidi käsitlemist vajava teemana nimetada laste-uurimuslikule teoreetilisele alusele toetuva mudeli otsimist, mis aitaks senisest paremini selgitada laste hulgas valitsevaid lapse kuvandeid.

Küsimustike erinevustest tingitud põhjustel jäid praegusest analüüsist kõrvale 453 õpilase (4.-6. klass) vastused. Kuna küsitlus ise on unikaalne ning selle teemad aktuaalsed ja olulised Eesti ühiskonnas, võiks küsitluse järgmiste 
lainete puhul püüda esitatud väiteid ühtlustada nii, et andmed oleksid kõigi vastajate puhul võrreldavad. Kitsendusena tuleb praeguse analüüsi puhul arvestada sedagi, et kasutatud uuringuandmete valimimetoodika ei võimaldanud laste ja täiskasvanute hinnangute kujunemise seoseid põhjalikumalt uurida, kuna laste ja täiskasvanute valimid polnud omavahel seotud.

Lapse kuvandi edasisel uurimisel oleks üks võimalus põlvkondlike erinevuste ja võimalike mõjude paremaks väljaselgitamiseks vaadata lapse kuvandeid näiteks peresisese uurimusena, mis annaks hea võimaluse luua selgemaid seoseid vanemate väärtushinnangute ja laste minapildi vahel, aga arvestada sealjuures ka erinevaid põlvkondi mõjutanud ajaloolis-kultuurilist konteksti. Samuti võiks teemat edasi uurida erinevate teadussuundade vaates, hõlmates näiteks psühholoogilisi ja arenguteoreetilisi lähtekohti.

Seega on esitatud tulemused esimene samm kirjeldamaks seda, millisena lapsi Eesti ühiskonnas nähakse. Saadud tulemused vajavad kindlasti jätkuanalüüsi ning täiendavat lahtimõtestamist, hõlmates sealjuures nii täiendavaid analüüsimeetodeid kui ka interdistsiplinaarset lähenemist laste ja täiskasvanute hoiakutele.

\section{Tänuavaldus}

Artikkel on valminud uurimisprojektide PUT1530 "Laste subjektiivne heaolu võrdlevas perspektiivis: metodoloogilised väljakutsed ja panus praktikasse" ja PRG700 "Lapsepõlve haavatavus ja haavatav subjektiivsus: interdistsiplinaarne võrdlev vaade" raames.

Autor tänab artikli valmimisele kaasa aitamise eest Dagmar Kutsarit ja Kairi Kasearu.

\section{Kommentaarid}

1 Mõned vastajad laste hulgas olid ka vanemad, kuid et nad kõik olid 11. klassi õpilased, vaadatakse neid analüüsis kui vanusrühma 10-17 kuulujaid.

2 Eeldusel, et igal lapsel on kaks vanemat ning et üksikvanemad ja kasuvanemad tasandavad oma arvukusega üksteist ära, leiti, et Eestis on ligikaudu 250000 lapsel (vanus 0-17) 500000 vanemat, mis moodustab ligikaudu poole 18-74aastastest elanikest (Koppel et al. 2018).

3 Täiskasvanute küsitlus toimus CAWI (ingl Computer Assisted Web Interview küsitletav täidab küsitlusankeedi iseseisvalt arvutiprogrammis/veebilehel) meetodil sarnastelt 7.-11. klassi küsitlusega. 4.-6. klassi puhul kasutati CAPI (ingl Computer Assisted Personal Interview - s.o silmast silma intervjuu, kus küsitleja esitab 
küsitletavale küsimused ja vastusevariandid ning seejärel sisestab küsitletav ise või küsitleja valitud vastused arvutiprogrammi) meetodit (Koppel et al. 2018).

4 Joonisel nähtavaid erinevusi laste ja täiskasvanute hinnangute vahel saab statistiliselt oluliseks pidada olulisuse nivool 0,01 enamiku väidete puhul, välja arvatud kolme väite puhul: lastel on oma arvamused ja eelistused, millega on oluline arvestada (erinevust väites oleks vea tõenäosus 0,204 ); lapsed on isekad ega arvesta teistega (erinevust väites oleks vea tõenäosus 0,498); lapsed teevad meelega pahandust, kui nad jätta järelevalveta (erinevust väites oleks vea tõenäosus 0,073). Kahe väite puhul võib erinevusi lugeda pigem olulisteks: lapsed ei ole võimelised asjadest aru saama $(p=0,051)$; lapsed ei suuda vastutada oma tegude eest $(p=0,045)$.

\section{Kirjandus}

Alanen, Leena 2014. Childhood and Intergenerationality: Toward an Intergenerational Perspective on Child Well-Being. Ben-Arieh, Asher \& Casas, Ferran \& Frønes, Ivar \& Korbin, Jill E. (toim). Handbook of Child Well-Being, Theories, Methods and Policies in Global Perspective. Dordrecht: Springer Science+Business Media, lk 131-160 (doi: 10.1007/978-90-481-9063-8_5).

Andrews, Arlene \& Ben-Arieh, Asher \& Carlson, Maya \& Damon, William \& Dweck, Carol \& Earls, Felton \& Coll, Cyntia Garcia \& Gold, Robert \& Halfon, Neal \& Hart, Roger \& Lerner, Richard M. \& McEwen, Bruce \& Meaney, Michael \& Offord, Dan \& Patrick, Donald \& Peck, Madga \& Trickett, Barbara \& Weisner, Thomas \& Zuckerman, Barry 2002. Ecology of Child Well-Being: Advancing the Science and the Science-Practice Link. Georgia: Centre for Child Well-Being (https://pdfs.semanticscholar.org/0da2/4b190943 af893b607e642e4f17d00ed40e03.pdf - 7. aprill 2020).

Anniste, Kristi \& Biin, Helen \& Osila, Liina \& Koppel, Kaupo \& Aaben, Laura 2018. Lapse õiguste ja vanemluse uuring 2018. Uuringu aruanne. Tallinn: Poliitikauuringute Keskus Praxis (https://www.sm.ee/sites/default/files/lovu_lopparuanne_final_1.11.18. pdf - 7. aprill 2020).

Ben-Arieh, Asher 2008. The child indicators movement: past, present and future. Child Indicators Research 1, lk 3-16.

Ben-Arieh, Asher \& Khoury-Kassabri, Mona. 2008. Attitudes Toward and Understanding of Children's Rights Among Middle School Students in Jerusalem: The Role of Family Values and Patterns, Nationality, and Religion. American Journal of Orthopsychiatry 78 (3), lk 359-368 (doi: 10.1037/a0014183).

Bronfenbrenner, Urie 1979. The Ecology of Human Development: Experiments by Nature and Design. Cambridge: Harvard University Press.

Brown, Timothy A. 2006. Confirmatory factor analysis for applied research. New York, London: The Guilford Press.

Bühler-Niederberger, Doris 2010. Introduction: Childhood Sociology - Defining the State of the Art and Ensuring Reflection. Current Sociology 58, lk 155-164 (doi: 10.1177/0011392109354239). 
Byrne, Barbara M. 2016. Structural Equation Modelling with AMOS. Basic Concepts, Applications, and Programming, Third Edition. New York: Routledge.

Corsaro, William A. 2011. The Sociology of Childhood. Los Angeles: Sage/Pine Forge Press.

Frønes, Ivar 1993. Changing Childhood. Childhood 1, lk 1-2 (doi: 10.1177/090756829300100101).

Goldson, Barry 1997. 'Childhood': An Introduction to Historical and Theoretical Analyses. Scraton, Phil (toim). 'Childhood' in 'Crisis'? London: UCL Press, lk 1-27.

Hendrick, H. 2015. Constructions and reconstructions of British childhood: an interpretative survey, 1800 to the present. James, Allison \& Prout, Alan (toim). Constructing and Reconstructing Childhood. Contemporary Issues in the Sociological Stury of Childhood. Oxon, New York: Routledge Education Classic Editions, lk 29-53.

James, Allison \& Prout, Alan 2015. Constructing and Reconstructing Childhood. Contemporary Issues in the Sociological Study of Childhood. Oxon, New York: Routledge Education Classic Editions.

Jonsson, Jan O \& Östberg, Viveca 2010. Studying Young People's Level of Living: The Swedish Child-LNU. Child Indicators Research 3 (1), lk 47-64 (doi: 10.1007/s12187-009-9060-8).

Jõers-Türn, Karin \& Kasearu, Kairi 2013. Teismeliste osalemine kodutöödes - kuivõrd on tüdrukutel suurem vastutus? Ariadne Lõng. Nais- ja meesuuringute ajakiri 1/2, lk 80-92.

Karu, Marre \& Turk, Pirjo \& Suvi, Hella \& Biin, Helen 2012. Lapse õiguste ja vanemluse monitooring. Metoodika aruanne. Poliitikauuringute Keskus Praxis (https://www.sm.ee/ sites/default/files/content-editors/Ministeerium_kontaktid/Uuringu_ja_analuusid/ Sotsiaalvaldkond/lapse_oiguste_ja_vanemluse_monitooring_-_kirjanduse_ylevaade_ ja_metoodika_aruanne.pdf - 8. aprill 2020).

Koppel, Kaupo \& Biin, Helen \& Osila, Liina \& Anniste, Kristi \& Aaben, Laura \& Piirits, Magnus \& Kukk, Kristiina \& Kask, Indrek 2018. Lapse õiguste ja vanemluse uuring. Metoodika aruanne. Poliitikauuringute Keskus Praxis (https://www.sm.ee/sites/default/ files/metaruanne_lovu_final.pdf - 8. aprill 2020).

Kutsar, Dagmar 2008. Lapse heaolu vananevas Eestis. Ots, Loone (toim). Uued ajaduued lapsed. Tallinn: Tallinna Ülikooli kirjastus, lk 96-111.

Minkkinen, Jaana 2013. The Structural Model of Child Well-Being. Child Indicators Research 6, lk 547-558.

Morrow, Virginia 2011. Understanding children and childhood. Centre for Children and Young People: Background Briefing Series 1. Australia, Lismore: Centre for Children and Young People, Southern Cross University.

Qvortrup, Jens 1987. Introduction. The sociology of childhood, special issue. International Journal of Sociology 17 (3), lk 3-37.

Qvortrup, Jens 1991. Childhood as a Social Phenomenon. An Introduction to a Series of National Reports. Eurosocial Reports 36. Viin: European Centre for Social Policy and Research.

Qvortrup, Jens 2014. Sociology: Societal Structure, Development of Childhood, and the Well-Being of Children. Ben-Arieh, A \& Casas, F \& Frønes, I \& Korbin, J. E (toim), 
Handbook of Child Well-Being, Theories, Methods and Policies in Global Perspective. Dordrecht: Springer Science+Business Media, lk 663-707.

Reinomägi, Andra 2020. Children's involvement and right to participate in the society: perspective of Estonian children and adults. Käsikiri, avaldamisel.

Scraton, Phil 1997. Whose 'Childhood'? What 'Crisis'? Scraton. Phil (toim). 'Childhood' in 'Crisis'? London: UCL Press, lk 167-190.

Tamm, Anni \& Kasearu, Kairi \& Tulviste, Tiia \& Trommsdorff, Gisela \& Saralieva, Zaratkhan K. M. 2016. Helping parents with chores or going out with friends. Cultural differences in adolescents' responses to potentially conflicting expectations of parents and peers. Journal of Adolescent Research, lk 1-23 (doi: 10.1177/0743558416637425).

Thompson, Ross A. 2014. Why Are Relationships Important to Children's Well-Being. Ben-Arieh, Asher \& Casas, Ferran \& Frønes, Ivar \& Korbin, Jill E. (toim). Handbook of Child Well-Being, Theories, Methods and Policies in Global Perspective. Dordrecht: Springer Science+Business Media, lk 1917-1954.

Tooding, Liina-Mai 2014. Faktoranalüüs. Statistilise andmeanalüüsi meetodid. Rootalu, Kadri \& Kalmus, Veronika \& Masso, Anu \& Vihalemm, Triin (toim). Sotsiaalse analüüsi meetodite ja metodoloogia õpibaas. Tartu Ülikool (http://samm.ut.ee/faktoranalyys 8. aprill 2020).

\title{
Summary
}

\section{How children are seen: Tracing perceptions through the eyes of adults and children}

\author{
Andra Reinomägi \\ Doctoral student in sociology \\ Institute of Social Studies, University of Tartu \\ andra.reinomagi@ut.ee
}

Keywords: children's position in society, image, perception and attitudes related to children, rights of the child

The article analyses the image of the child as perceived from the perspective of children and adults and determines to what extent the perceptions vary between the children and adults. For this purpose, views of children widespread among children and adults are compared. The paper also examines the sociodemographic background of the adults who represent these beliefs. The analysis is based on data from the Estonian Children's Rights and Parenting Survey (2018), which gives a unique opportunity to compare opinions held by children and adults using the same methodology. The data compared against adults' responses in this analysis came from the two older stages of study in school (7th to 11th grades). The sample size in this analysis is 624 schoolchildren. The adults' sample consists of 1,248 responses in the age group 18-74.

The statements used in the study were selected based on approaches mentioned in theoretical literature for describing definite categories of how children are perceived: 
children as a) immature; b) competent; c) vulnerable; d) irresponsible. Whereas in the case of adults, the theoretical model can be considered valid, the results of this analysis showed that the responses from Estonian children were at slight variance with theorized perceptions. Four perceptions of children could be distinguished from the responses from Estonian children, and they can be described as follows: 1) children as selfish and irresponsible; 2) children as competent and independent; 3) children as vulnerable and in need of protection and supervision yet having their own opinions important to be considered; 4) children as innocent and immature.

The findings show that, as compared to children, adults often see children as vulnerable, fragile individuals needing protection and who, lacking knowledge, need advice and supervision. Adults also strongly support the image of the competent child, which holds that children have their own opinion and preferences, that are considered important to be taken into account. Children themselves frequently see themselves as competent, while their responses also reflect a perceived need for protecting children and supervision by adults.

The findings of this study allow us to conclude that the model of perceptions of children created by adults on the basis of theoretical literature for describing how children are perceived is suitable for adults but not so much for children. Children view children differently than adults, and their attitudes can be grouped differently from those of adults: children themselves construct a different image of themselves than adults.

These collective images shape everyday reality for children and the beliefs related to children, and thereby also mould people's behaviour. This analysis indicates that the way in which children are seen is related to the gender and ethnicity of the adult respondents and also to whether the respondents have minor children of their own. These findings allow us to conclude that cultural context is significantly related to how children are perceived. Education has an important role as well - people with higher education tend to see children as competent. One particular finding of interest is that the way in which children are seen by adult respondents depends on whether the adults have heard of the concept of the rights of the child. Those who are well abreast of the concept tend to see children as competent with fewer of those who consider children immature. Thus, it appears that awareness of the rights of the child and human rights education in general is extremely important for improving children's opportunities to have a say on matters concerning themselves and society in general.

The results of the study reflect children's position in society, help to make sense of the relationships between children and adults and can serve as a basis for further research into describing the situation of children and opportunities. This analysis provides a first overview of what types of children's perceptions groups could be traced from the attitudes expressed by children and adults.

Andra Reinomägi on Tartu Ülikooli Ühiskonnateaduste instituudi sotsioloogia doktorant. Tema peamised uurimisteemad on seotud laste heaolu ja lapse õiguste uurimisega lähtuvalt lapse perspektiivist.

Andra Reinomägi is a doctoral student of sociology at the Institute of Social Studies at the University of Tartu. Her primary research interests are child's well-being and rights of the child from the child's perspective. 